\title{
Enhancement of thermoalkaliphilic xylanase production by Pichia pastoris through novel fed-batch strategy in high cell-density fermentation
}

Tingting Shang ${ }^{1 \dagger}$, Dayong $\mathrm{Si}^{1+}$, Dongyan Zhang ${ }^{1}$, Xuhui Liu' ${ }^{1}$, Longmei Zhao ${ }^{1,2}$, Cong Hu${ }^{1}$, Yu Fu ${ }^{1}$ and Rijun Zhang ${ }^{1 *}$

\begin{abstract}
Background: Xylanase degrades xylan into monomers of various sizes by catalyzing the endohydrolysis of the 1,4- $\beta$-Dxylosidic linkage randomly, possessing potential in wide industrial applications. Most of xylanases are susceptible to be inactive when suffering high temperature and high alkaline process. Therefore, it is necessary to develop a high amount of effective thermoalkaliphilic xylanases. This study aims to enhance thermoalkaliphilic xylanase production in Pichia pastoris through fermentation parameters optimization and novel efficient fed-batch strategy in high cell-density fermentation.

Results: Recombinant xylanase activity increased $12.2 \%, 7.4 \%, 12.0 \%$ and $9.9 \%$ by supplementing the Pichia pastoris culture with $20 \mathrm{~g} / \mathrm{L}$ wheat bran, $5 \mathrm{mg} / \mathrm{L} \mathrm{L}$-histidine, $10 \mathrm{mg} / \mathrm{L} \mathrm{L}$-tryptophan and $10 \mathrm{mg} / \mathrm{L} \mathrm{L}$-methionine in shake flasks, respectively. Investigation of nutritional fermentation parameters, non-nutritional fermentation parameters and feeding strategies in $1 \mathrm{~L}$ bioreactor and $1 \mathrm{~L}$ shake flask revealed that glycerol and methanol feeding strategies were the critical factors for high cell density and xylanase activity. In $50 \mathrm{~L}$ bioreactor, a novel glycerol feeding strategy and a four-stage methanol feeding strategy with a stepwise increase in feeding rate were developed to enhance recombinant xylanase production. In the initial $72 \mathrm{~h}$ of methanol induction, the linear dependence of xylanase activity on methanol intake was observed $\left(R^{2}=0.9726\right)$. The maximum xylanase activity was predicted to be $591.2 \mathrm{U} / \mathrm{mL}$, while the actual maximum xylanase activity was $560.7 \mathrm{U} / \mathrm{mL}$, which was 7.05 times of that in shake flask. Recombinant xylanase retained $82.5 \%$ of its initial activity after pre-incubation at $80^{\circ} \mathrm{C}$ for $50 \mathrm{~min}(\mathrm{pH} \mathrm{8.0)}$, and it exhibited excellent stability in the broad temperature $\left(60-80^{\circ} \mathrm{C}\right)$ and $\mathrm{pH}(\mathrm{pH} 8.0-11.0)$ ranges.

Conclusions: Efficient glycerol and methanol fed-batch strategies resulting in desired cell density and xylanase activity should be applied in other $P$. pastoris fermentation for other recombinant proteins production. Recombinant xylanases with high $\mathrm{pH}$ - and thermal-stability showed potential in various industrial applications.
\end{abstract}

Keywords: Thermoalkaliphilic xylanase, Pichia pastoris, Fermentation parameter optimization, Bioprocess, Fed-batch strategy, High cell-density fermentation

\footnotetext{
*Correspondence: feedbiotech@yahoo.com

†Equal contributors

'Laboratory of Feed Biotechnology, State Key Laboratory of Animal Nutrition, College of Animal Science \& Technology, China Agricultural University, No.2

Yuanmingyuan West RoadHaidian District, Beijing 100193, China

Full list of author information is available at the end of the article
} 


\section{Background}

Xylan is the major component of hemicellulose, and it is the second most abundant renewable resource [1]. Xylanase ( $\beta$-1,4-Endoxylanases, EC 3.2.1.8) degrades xylan into monomers by catalyzing the endohydrolysis of the $1,4-\beta$ $\mathrm{D}$-xylosidic linkage between molecules of xylose in the main chain randomly [2]. Lignocellulosic matter consists of ca. $40 \%$ cellulose, $33 \%$ hemicellulose, and 23\% lignin by dry weight [3]. Endoxylanases play an important role in bioconversion of lignocellulose in feed, food, biofuel, pulp and paper industry and are widely used as raw materials in lots of industrial processes [2, 4].

Thermoalkaliphilic xylanases are required in detergent, textile, paper and pulp industries. With them, enzymes hydrolysis will be performed at elevated temperatures without cooling substrate down, thus process time will be shortened, energy will be saved and saccharification yield can be improved, leading to a more economical and feasible process [5]. Up to now, a large number of xylanases have been produced and investigated, however, most of xylanases are susceptible to denaturation when exposed to the high temperature and high alkaline process [6]. Therefore, the development of a high amount of effective thermoalkaliphilic xylanases is highly desirable.

With the development of recombinant protein engineering, genetic engineering strains are employed to produce recombinant xylanase effectively. The methylotrophic yeast Pichia pastoris (P. pastoris), one of the most extensively used expression systems for heterologous proteins production, has many advantages: (1) generally strong and tightly regulated promoters, (2) available molecular manipulation tools, (3) high cell-density fermentation on inexpensive substrate, (4) protein production in secretory fashion [7, 8]. Unlike extremozyme production by extremophile under unusual condition, the bioprocess of extremozyme production by mesophilic host organisms such as $P$. pastoris can be optimized for high biomass and enzyme activity. Therefore, expression of thermoalkaliphilic xylanases in $P$. pastoris is attractive.

Different micro-organisms have different physiological phenotype and biosynthetic capacity, thus fermentation parameters including growth medium composition and cultivation conditions $(\mathrm{pH}$, temperature, dissolved oxygen (DO), etc.) affect producing cells growth and recombinant xylanase production [9]. The levels of recombinant protein production in $P$. pastoris in bioreactor cultures are typically much higher than those in shake-flask cultures [10], since these factors including $\mathrm{pH}$, temperature, oxygen transfer and substrate addition can be monitored and controlled simultaneously. In bioreactor cultures, $P$. pastoris can grow to high cell density (exceeding $100 \mathrm{~g} / \mathrm{L}$ dry cell weight $(\mathrm{DCW}))[11,12]$, and a large amount of recombinant proteins production is based on high concentration of producing cells in the culture [13]. For $P$. pastoris expression system, alcohol oxidase 1 (AOX1) promoter has been the most widely reported and utilized, which can be regulated by methanol for recombinant proteins production [14]. Therefore, cultivation of $P$. pastoris is normally separated into three phases: batch phase, where cells grow until initial carbon source has been exhausted; fed-batch phase, where the same carbon source is fed for high cell density; induction phase, recombinant protein is induced to produce by feeding inducer after initial carbon source exhaustion [15-17]. Nutrient feeding strategy is critical for recombinant proteins production by $P$. pastoris in high cell-density fermentation. Glycerol is a common initial carbon source, while it may repress the AOX1 promoter and lower recombinant proteins production $[18,19]$. The inducer methanol excessing a certain level is cytotoxic and inhibits cells growth [20]. To prevent overfeeding of nutrients, feedback-controlled feeing systems are developed, in which the nutrient is added according to a change in $\mathrm{DO}, \mathrm{pH}$, substrate concentration or by-product (often has negative effects on targeted recombinant protein production) concentration [21-24].

In previous study, the $x y n A$ xylanase gene from Thermobiafida fusca YX was cloned and expressed in $P$. pastoris X-33. Thermobifida fusca is a thermophilic actinomycete and a major degrader of plant cell walls in heated organic materials. This recombinant xylanase was optimally active at $80{ }^{\circ} \mathrm{C}$ and $\mathrm{pH} 8.0$ [25]. In the present study, we optimized fermentation parameters and developed novel glycerol and methanol fed-batch strategies to enhance recombinant thermoalkaliphilic xylanase production in $P$. pastoris in high cell-density fermentation in $50 \mathrm{~L}$ bioreactor.

\section{Methods}

\section{Strains and reagents}

To obtain the secreted thermoalkaliphilic xylanase, a $P$. pastoris strain $\mathrm{X}-33$ transformed with $\mathrm{pPICZa-A}$ vector bearing the construct $x y n A$ of Thermobifida fusca $\mathrm{YX}$ with a C-terminal histidine tag locates at the downstream of AOX1 promoter was used, and the xylanase was optimally active at $80{ }^{\circ} \mathrm{C}$ and $\mathrm{pH} 8.0$ [25]. Yeast extract and peptone were obtained from OXOID (Basingstoke, Hampshire, $\mathrm{UK}$ ), yeast nitrogen base (YNB) without amino acids was purchased from BD (Sparks, MD, USA), biotin and phenylmethylsulfonyl fluoride (PMSF) were obtained from Amresco (Solon, OH, USA). Xylan from beechwood was purchased from Sigma Chemical Company (St. Louis, MO, USA). Xylose was from Wako (Osaka, Japan). Corn bran, corncob, cottonseed hull and wheat bran were purchased from Xiangchi (Shandong, China), Chunjing (Guangdong, China), Hengfeng Mining (Hebei, China) and Zhongnongzhenya (Beijing, China), respectively. All 
of the lignocellulosic materials passed through $0.2-\mathrm{mm}$ screen sieve. Other chemicals were obtained from Sinopharm Chemical Reagent Co., Ltd (Shanghai, China).

\section{Cultivation of recombinant $P$. pastoris in shake flask}

Yeast extract peptone dextrose (YPD) plates for seed cultivation contained $10 \mathrm{~g} / \mathrm{L}$ yeast extract, $20 \mathrm{~g} / \mathrm{L}$ peptone, $20 \mathrm{~g} / \mathrm{L}$ dextrose and $20 \mathrm{~g} / \mathrm{L}$ agar. A single colony was inoculated in $50 \mathrm{~mL}$ buffered glycerol-complex medium (BMGY, $10 \mathrm{~g} / \mathrm{L}$ yeast extract, $20 \mathrm{~g} / \mathrm{L}$ tryptone, $13.4 \mathrm{~g} / \mathrm{L} \mathrm{YNB}, 4 \times 10^{-4} \mathrm{~g} / \mathrm{L}$ biotin, $100 \mathrm{mM}$ potassium phosphate ( $\mathrm{pH} 6.0), 1 \%(\mathrm{v} / \mathrm{v})$ glycerol), and incubated at $30{ }^{\circ} \mathrm{C}, 220 \mathrm{rpm}$ for $24 \mathrm{~h}$ in a $500 \mathrm{~mL}$ baffled shake flask, then $5 \mathrm{~mL}$ of the culture was transferred into $100 \mathrm{~mL}$ BMGY medium in $1 \mathrm{~L}$ baffled shake flask and cultured at the same condition. To select the optimal carbon source, xylanase activity and DCW were determined with $1 \%(\mathrm{w} / \mathrm{v})$ glucose or $1 \%(\mathrm{w} / \mathrm{v})$ maltose as carbon source to replace $1 \%(\mathrm{v} / \mathrm{v})$ glycerol in the BMGY medium. After incubation for $60 \mathrm{~h}, 0.5 \%(\mathrm{v} / \mathrm{v})$ methanol was added every $24 \mathrm{~h}$. The culture was sampled at $0 \mathrm{~h}$ and $24 \mathrm{~h}$ of fermentation, and then every $12 \mathrm{~h}$. We also investigated the xylanase activity and DCW with $1 \%(\mathrm{v} /$ v) glycerol or $1 \%(\mathrm{w} / \mathrm{v})$ glucose as the initial carbon source, and $0.5 \%(\mathrm{v} / \mathrm{v})$ methanol was added every $24 \mathrm{~h}$ after inoculation. To obtain highly active xylanase, 2\% $(\mathrm{w} / \mathrm{v})$ tryptone in the BMGY medium was replaced by various nitrogen sources $\left(2 \%\left(\mathrm{NH}_{4}\right)_{2} \mathrm{SO}_{4}, 2 \%\left(\mathrm{NH}_{2}\right)_{2} \mathrm{CO}\right.$, $2 \%$ soya peptone, $2 \%(\mathrm{v} / \mathrm{v})$ ammonia solution $(\mathrm{pH} 6.0)$ ). To study the effect of amino acid, protease inhibitor and lignocellulosic material on xylanase production, recombinant $P$. pastoris was cultured in BMGY medium supplemented with $5 \mathrm{mg} / \mathrm{L}$ L-histidine, $10 \mathrm{mg} / \mathrm{L} \mathrm{L}$-tryptophan, $10 \mathrm{mg} / \mathrm{L}$ L-methionine, $1 \mathrm{mM}$ PMSF, $1 \mathrm{mM}$ ethylenediaminetetraacetic acid (EDTA), $20 \mathrm{~g} / \mathrm{L}$ corn bran, $20 \mathrm{~g} / \mathrm{L}$ corncob, $20 \mathrm{~g} / \mathrm{L}$ cottonseed hull, $20 \mathrm{~g} / \mathrm{L}$ wheat bran, $10 \mathrm{~g} / \mathrm{L}$ corn bran $+10 \mathrm{~g} / \mathrm{L}$ wheat bran, $10 \mathrm{~g} / \mathrm{L}$ corncob $+10 \mathrm{~g} / \mathrm{L}$ wheat bran, and $10 \mathrm{~g} / \mathrm{L}$ cottonseed hull $+10 \mathrm{~g} / \mathrm{L}$ wheat bran for $96 \mathrm{~h}$, respectively. Methanol $(0.5 \%(\mathrm{v} / \mathrm{v}))$ was added every $24 \mathrm{~h}$ to maintain induction. Samples were collected at $96 \mathrm{~h}$ for xylanase activity analysis.

\section{Cultivation of recombinant $P$. pastoris in $1 \mathrm{~L}$ bioreactor}

Seed culture was prepared in BMGY medium at $30{ }^{\circ} \mathrm{C}$, $220 \mathrm{rpm}$ in baffled shake flask for $24 \mathrm{~h}$. Seed culture $(30 \mathrm{~mL})$ was inoculated to $600 \mathrm{~mL}$ BMGY medium supplemented with $3.0 \mathrm{mg}$ L-histidine, $6.0 \mathrm{mg}$ L-tryptophan, $6.0 \mathrm{mg} \mathrm{L}$-methionine and $12.0 \mathrm{~g}$ wheat bran in $1 \mathrm{~L}$ bioreactor. Cultivation was conducted at $30{ }^{\circ} \mathrm{C}, 800 \mathrm{rpm}$. The $\mathrm{pH}$ was maintained at 6.0 with $28 \%(\mathrm{w} / \mathrm{v}) \mathrm{NH}_{4} \mathrm{OH}$ and DO was kept above $20 \%$. Different treatments were performed: I) for $1 \mathrm{~L}$ bioreactors, the glycerol growth phase was maintained for $24 \mathrm{~h}$ by feeding $1 \%(\mathrm{v} / \mathrm{v})$ glycerol at $9 \mathrm{~h}$ and $17 \mathrm{~h}$, the methanol induction phase was maintained for following $120 \mathrm{~h}$ by feeding $0.5 \%(\mathrm{v} / \mathrm{v})$ methanol at inoculated time of $24 \mathrm{~h}, 32 \mathrm{~h}, 48 \mathrm{~h}$, then every $8 \mathrm{~h}$ to the end; II) for the other $1 \mathrm{~L}$ bioreactors, $0.5 \%(\mathrm{v} / \mathrm{v})$ methanol was added every $24 \mathrm{~h}$ after inoculation; III) P. pastoris expressed xylanase in $100 \mathrm{~mL}$ BMGY medium without supplementation of amino acids and wheat bran in $1 \mathrm{~L}$ shake flasks at $30{ }^{\circ} \mathrm{C}, 220 \mathrm{rpm}$, but having the same glycerol and methanol feeding strategies with treatment II.

\section{Cultivation of recombinant $P$. pastoris in $50 \mathrm{~L}$ bioreactor}

Seed culture $(1.25 \mathrm{~L})$ was inoculated to $25 \mathrm{~L}$ basal salt medium as $\mathrm{Li}$ et al. described, and $\left(\mathrm{NH}_{4}\right)_{2} \mathrm{SO}_{4}$ was replaced by $\left(\mathrm{NH}_{2}\right)_{2} \mathrm{CO}$ in a $50 \mathrm{~L}$ bioreactor (Baoxing Co., Shanghai, China) [26]. In addition, we added $0.125 \mathrm{~g} \mathrm{L-}$ histidine, $0.25 \mathrm{~g}$ L-tryptophan, $0.25 \mathrm{~g}$ L-methionine and $500 \mathrm{~g}$ wheat bran into the $50 \mathrm{~L}$ bioreactor. Temperature was maintained at $30^{\circ} \mathrm{C}$ by water cooling, $\mathrm{pH}$ was automatically adjusted to 6.0 with $28 \%(\mathrm{w} / \mathrm{v}) \mathrm{NH}_{4} \mathrm{OH}$, the agitation rate ranged from 200 to $350 \mathrm{rpm}$, and the tank pressure was 0.7 bar. A total cultivation time of $120 \mathrm{~h}$ included glycerol growth stage (0-24 h) and methanol induction stage $(25-120 \mathrm{~h})$. Glycerol cultivation was divided into three phases: batch phase $(0-19 \mathrm{~h})$ : cells grew until the initial carbon source glycerol was depleted, which was indicated by a sudden increase in DO; fedbatch phase $(20-22 \mathrm{~h}): 50 \%(\mathrm{v} / \mathrm{v})$ glycerol containing $1.2 \%(\mathrm{v} / \mathrm{v})$ PTM1 trace salt solution was fed at the rate of $10.4 \mathrm{~mL} \mathrm{~h}^{-1} \mathrm{~L}^{-1}$; starvation phase (23-24 h): glycerol feeding was stopped, and depletion of glycerol was indicated by DO rose to $100 \%$. For methanol induction, feeding manner of $100 \%(\mathrm{v} / \mathrm{v})$ methanol containing $1.2 \%$ (v/v) PTM1 trace salt solution was shown in the Table 1. Samples were collected every $12 \mathrm{~h}$.

\section{Determination of DCW}

Five milliliters of culture broth was placed in preweighed tube and centrifuged at 12,000 rpm for $5 \mathrm{~min}$. The supernatant was removed and stored at $-20{ }^{\circ} \mathrm{C}$ for xylanase activity analysis. The tube was dried at $100{ }^{\circ} \mathrm{C}$ to a constant weight, and then DCW was calculated and reported as $\mathrm{g} / \mathrm{L}$ (g DCW per L of culture).

\section{Determination of xylanase activity}

The xylanase activity was determined by measuring the reducing sugar released from beechwood xylan with dinitrosalicylic acid (DNS) method [27, 28]. The reaction

Table 1 Methanol feeding rate in methanol induction phase

\begin{tabular}{lllll}
\hline \multicolumn{5}{c}{ Methanol feeding rate $\left(\mathrm{mL} \mathrm{h}^{-1} \mathrm{~L}^{-1}\right)$} \\
\hline & 0.8 & 1.2 & 1.6 & 1.8 \\
Induction time $(\mathrm{h})$ & $0-12$ & $13-24$ & $25-48$ & $49-96$ \\
\hline
\end{tabular}


mixture contained $20 \mu \mathrm{L}$ of appropriately diluted crude enzyme solution and $180 \mu \mathrm{L}$ of $1 \%(\mathrm{w} / \mathrm{v})$ beechwood xylan in $50 \mathrm{mM}$ phosphate buffer ( $\mathrm{pH} 8.0)$. After being incubated at $80{ }^{\circ} \mathrm{C}$ for $20 \mathrm{~min}$, the reaction was terminated by chilling the mixture on ice and adding $200 \mu \mathrm{L}$ of DNS solution. After boiling sample for $10 \mathrm{~min}$, the absorbance of $200 \mu \mathrm{L}$ sample at $540 \mathrm{~nm}$ was measured by iMark Microplate Reader (Bio-Rad, Hercules, CA, USA). One unit of xylanase activity was defined as the amount of xylanase releasing $1 \mu$ mole of reducing sugar per minute under the assay condition (with xylose as a standard).

\section{Characterization of the recombinant xylanase}

To determine the effect of $\mathrm{pH}$ on xylanase stability, xylanase was pre-incubated at $50{ }^{\circ} \mathrm{C}$ in different $\mathrm{pH}$ buffers $(\mathrm{pH} 8.0$ using sodium phosphate buffer, $\mathrm{pH}$ 9.0-11.0 using glycine- $\mathrm{NaOH}$ buffer) for $0,1,2,3,5,7,9,11 \mathrm{~h}$. Samples were taken at different time intervals and xylanase residual activity was measured according to the above method after cooling.

To evaluate thermal stability, xylanase was preincubated at $60{ }^{\circ} \mathrm{C}, 70{ }^{\circ} \mathrm{C}, 80^{\circ} \mathrm{C}$ and $90{ }^{\circ} \mathrm{C}$ for $0,5,10$, $15,20,25,30,40,50$ and $60 \mathrm{~min}$. Samples were taken at different time intervals. After cooling, residual activity of treated xylanase was assayed according to the above method.

\section{Statistical analysis}

The SPSS 17.0 statistical software package and software Microsoft Excel 2010 were used to analyze and plot the experimental data. The data were expressed as the means \pm standard deviations. The differences among the groups were analyzed by one-way analysis variance (ANOVA) followed by Duncan's method. A $p$-value less than 0.05 was considered statistically significant.

\section{Results and discussion}

Effect of carbon source on DCW and xylanase activity in shake flask

Carbon source provides energy and carbon skeletons for $P$. pastoris cells growth and recombinant protein production. The xylanase activity was almost zero before induction with glycerol or glucose as initial carbon source (Fig. 1a). It meant that P. pastoris cells growth could be supported by glycerol or glucose, however, xylanase gene expression driven by AOX1 promoter can't be induced in glycerol- or glucose-containing medium, which was in agreement with Hellwig's report [29]. When 0.5\% (v/v) methanol was added at $60 \mathrm{~h}$, the xylanase activity increased in the medium whose initial carbon source was glucose or glycerol, and it was always higher than that in the medium with maltose as initial carbon source. There was almost no change in DCW after fermentation for $24 \mathrm{~h}$ in glycerol- or glucose-grown $P$. pastoris cultivation, while the DCW was lower at the beginning of fermentation and increased with the time in maltose-grown P. pastoris cultivation (Fig. 1a). We also investigated the DCW and xylanase activity in glycerol- and glucosegrown $P$. pastoris cultivation when $0.5 \%(\mathrm{v} / \mathrm{v})$ methanol was added every $24 \mathrm{~h}$ after inoculation (Fig. 1b), and the maximum xylanase activity in both glycerol-grown and glucose-grown $P$. pastoris cultivation detected at $84 \mathrm{~h}$ was about $75.0 \mathrm{U} / \mathrm{mL}$ and kept more or less the same until $108 \mathrm{~h}$. After fermentation for $24 \mathrm{~h}$, the DCW ranged from $13.53 \mathrm{~g} / \mathrm{L}$ to $14.43 \mathrm{~g} / \mathrm{L}$ with glycerol as initial carbon source, and it ranged from $10.75 \mathrm{~g} / \mathrm{L}$ to $13.23 \mathrm{~g} / \mathrm{L}$ with glucose as initial carbon source (Fig. 1b). Glucose, one of fermentative carbon sources, tends to be avoid in favor of the non-fermentative carbon source glycerol, because the by-product ethanol may repress the AOX1 promoter for recombinant protein production $[10,30]$. In this study, glycerol was treated as the optimal initial carbon source.
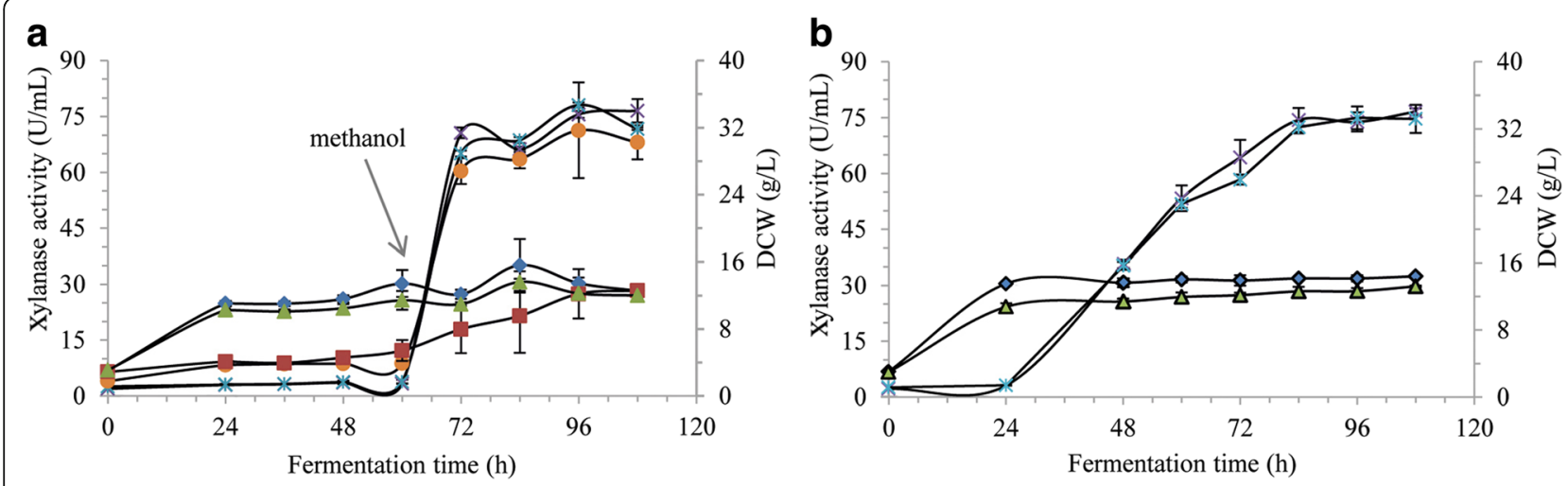

Fig. 1 DCW and xylanase activity profiles with xylanase expression at different carbon sources in shake flask. a methanol was added after fermentation for 60 h, b methanol was added every 24 h. Circles, xylanase activity (maltose); asterisks, xylanase activity (glucose); crosses, xylanase activity (glycerol); triangles, DCW (glucose); squares, DCW (maltose); diamonds, DCW (glycerol) 


\section{Supplementation of wheat bran improved xylanase activity in shake flask}

Lignocellulosic material contains a plenty of xylan and other nutrients. It may serve as substrate for cells growth or inducer for hemicellulose enzyme production, [31]. BMGY medium supplemented with lignocellulosic materials (corn bran, wheat bran, cottonseed hull and corncob) was used for xylanase production in P. pastoris. The xylanase activity was significantly improved by supplementing 2\% (w/v) wheat bran (Fig. 2a). Wheat bran can provide high quality proteins, minerals, and phenolic and bioacitve carbohydrate after enzymatical hydrolysis [32-34], which may be benefit for $P$. pastoris cells growth and recombinant xylanase production. In previous studies, corncob could be used by filamentous fungi (Rhizopus stolonifer JS-1008, Streptomyces sp. CS802, Aspergillus niger CECT 2700, etc.) for xylanase production [35-37]. However, the xylanase activity was decreased by $70.31 \%$ with adding $2 \%(\mathrm{w} / \mathrm{v})$ corncob to $P$. pastoris culture in this study (Fig. 2a).

Effect of nitrogen source on xylanase activity in shake flask Nitrogen source plays an important role in the growth of micro-organisms and metabolite production. To study the effect of nitrogen source on xylanase activity, tryptone in BMGY medium was replaced by one organic nitrogen source - soya peptone and three inorganic nitrogen sources - $\left(\mathrm{NH}_{2}\right)_{2} \mathrm{CO},\left(\mathrm{NH}_{4}\right)_{2} \mathrm{SO}_{4}$ and $\mathrm{NH}_{4} \mathrm{OH}$ (pH 6.0), respectively. As shown in Fig. 2b, when tryptone was used as nitrogen source, the highest xylanase activity reached $71.3 \mathrm{U} / \mathrm{mL}$ at $96 \mathrm{~h}$, and the second highest xylanase activity was $61.3 \mathrm{U} / \mathrm{mL}$ with $\left(\mathrm{NH}_{2}\right)_{2} \mathrm{CO}$ as nitrogen source. No obvious difference in xylanase activity was observed when $\mathrm{NH}_{4} \mathrm{OH}(\mathrm{pH} 6.0),\left(\mathrm{NH}_{4}\right)_{2} \mathrm{SO}_{4}$ or soya peptone was used. For economical and commercial purpose, $\left(\mathrm{NH}_{2}\right)_{2} \mathrm{CO}$ has potential application in largescale fermentation.

\section{Supplementation of amino acid and protein inhibitor improved xylanase activity in shake flask}

When adding PMSF to the medium, xylanase activity was increased from $102.3 \mathrm{U} / \mathrm{mL}$ to $106.7 \mathrm{U} / \mathrm{mL}(P<0.05)$, it can be inferred that extracellular proteases were produced during xylanase production in P. pastoris. Some researchers indicated that supplementation of amino acids improved recombinant protein production [38], and addition of casamino acids could protect protein expressed by $P$. pastoris from proteolytic degradation [39]. The xylanase activity was

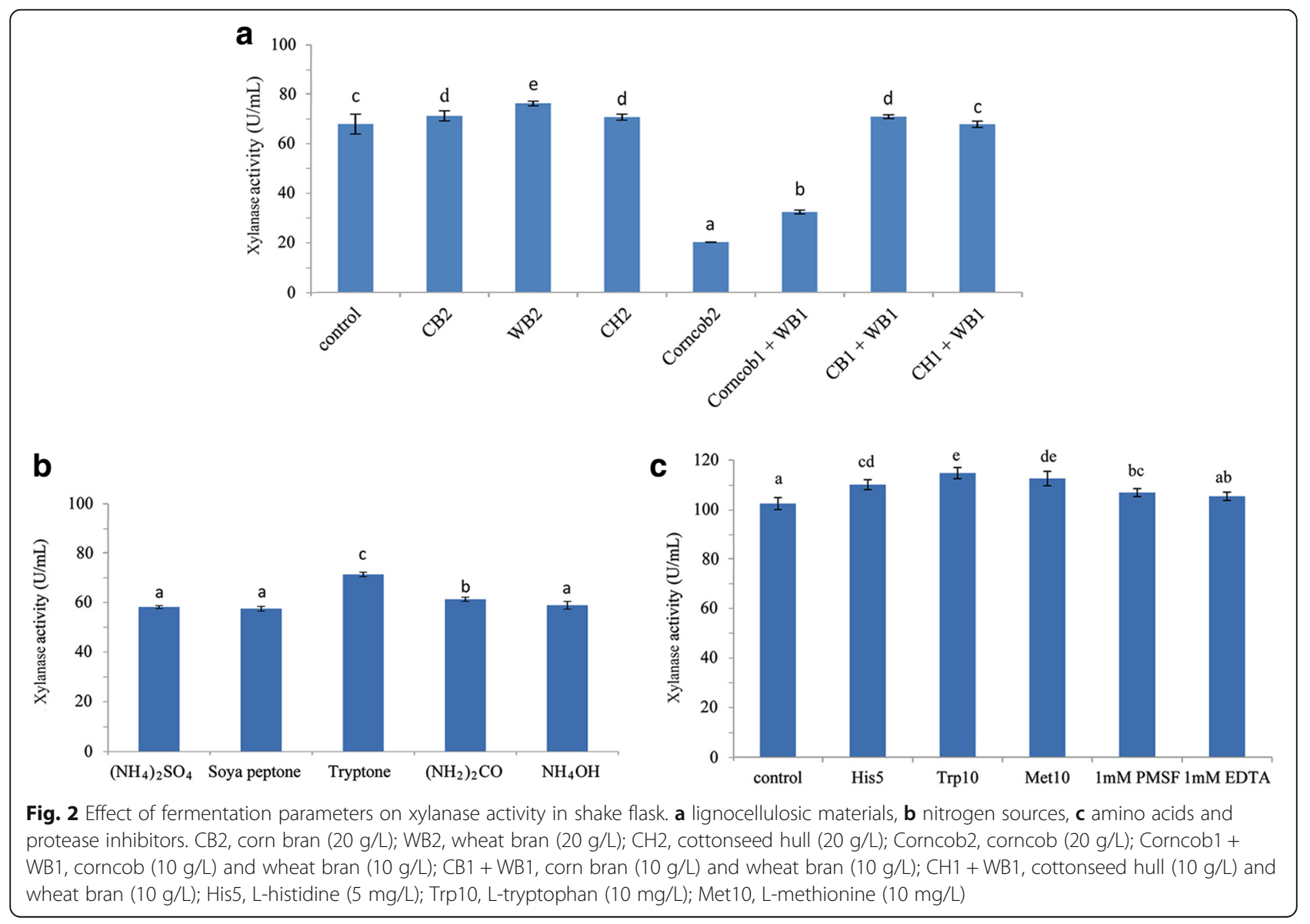


increased by $7.4 \%, 12.0 \%$ and $9.9 \%$ when supplemented BMGY medium with $5 \mathrm{mg} / \mathrm{L}$ L-histidine, $10 \mathrm{mg} / \mathrm{L}$ L-tryptophan and $10 \mathrm{mg} / \mathrm{L}$ L-methionine, respectively (Fig. 2c). Besides acting as alternative and competing substrates to decrease hydrolysis of target protein, sufficiently available exogenous amino acids in nitrogen-metabolism can be incorporared directly into biomass [40].

\section{Xylanase production in $P$. pastoris in $1 \mathrm{~L}$ bioreactor and 1 L shake flask}

Singh et al. reported that the recombinant protein produced in bioreactor was significantly higher than that in shake flask [41]. As shown in Fig. 3, DCW in all of the treatments was stable after $48 \mathrm{~h}$, however, DCW in treatment I was $45.05 \mathrm{~g} / \mathrm{L}$ at $96 \mathrm{~h}$, significantly higher than those in treatment II $(26.73 \mathrm{~g} / \mathrm{L})$ and treatment III $(14.48 \mathrm{~g} / \mathrm{L})$. It can be inferred that DCW was highly correlated to glycerol content. The maximum xylanase activity reached $114.1 \mathrm{U} / \mathrm{mL}$ in treatment II and 108.8 $\mathrm{U} / \mathrm{mL}$ in treatment III at $72 \mathrm{~h}$, however, the maximum xylanase activity was $224.4 \mathrm{U} / \mathrm{mL}$ at $96 \mathrm{~h}$ in treatment I. These results obviously suggested that glycerol and methanol feeding strategies were the critical factors in high DCW and xylanase activity. In treatment I, glycerol had already been depleted at $24 \mathrm{~h}$ of fermentation, which was indicated by a spike in DO, and then pulsed addition of $6 \mathrm{ml}$ of methanol $(50 \%(\mathrm{v} / \mathrm{v}))$ in the $600 \mathrm{~mL}$ BMGY medium was performed at $24 \mathrm{~h}, 32 \mathrm{~h}, 48 \mathrm{~h}$, and then every $8 \mathrm{~h}$ to the end of fermentation in $1 \mathrm{~L}$ bioreactors. When $P$. pastoris cells were growing with sufficient carbon source, DO was strongly demanded for carbon source assimilation, as a result the DO tension fell and became very low; while the DO tension increased sharply once carbon source was depleted. According to these phenomena, the methanol depletion time from the time point pulsed addition of methanol to the time point

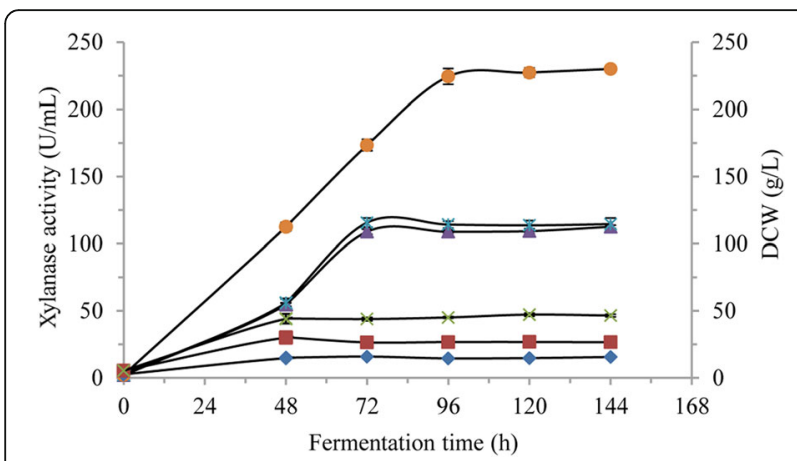

Fig. 3 Recombinant xylanase production in P.pastoris in $1 \mathrm{~L}$ bioreactor and $1 \mathrm{~L}$ shake flask. Circles, xylanase activity in treatment I; asterisks, xylanase activity in treatment II; triangles, xylanase activity in treatment III; crosses, DCW in treatment I; squares, DCW in treatment II; diamonds, DCW in treatment III when DO rose to $50 \%$ again was recorded and shown in Fig. 4. In general, methanol consumption rate increased in the initial $64 \mathrm{~h}$ and then showed a tendency of decrease, and the result also suggested methanol was insufficient in P. pastoris cultivation (Fig. 4).

\section{Development of novel glycerol and methanol fed-batch strategies in $50 \mathrm{~L}$ bioreactor}

Based on the above findings, novel glycerol and methanol fed-batch strategies were adopted to improve DCW and xylanase activity in $50 \mathrm{~L}$ bioreactor, where glycerol and methanol feeding rates, $\mathrm{DO}, \mathrm{pH}$ and temperature could be easily controlled and monitored. Glycerol enters glycolysis and requires respiration to oxidize $\mathrm{NADH}$ to serve as energy source [18]. A lower initial glycerol concentration and fed-batch operation led to a higher cell growth rate and desired biomass [23], and the concentration of the producing cells in the medium affects the volumetric productivity of recombinant enzymes [13]. In this study, glycerol cultivation (total $24 \mathrm{~h})$ consisted of batch phase $(0-19 \mathrm{~h})$, fed-batch phase $(20-22 \mathrm{~h})$ and starvation phase (23-24 h). After culturing $P$. pastoris in glycerol-containing medium for $24 \mathrm{~h}$, depletion of glycerol was indicated by DO rose to $100 \%$, and the DCW reached $41.8 \mathrm{~g} / \mathrm{L}$, but almost no xylanase activity was detected (Fig. 5), which indicated AOX1 promoter could be tightly regulated by methanol, and glycerol catabolic process was relatively independent of the methanol metabolism pathways [42]. Weinhandl et al. also reported glycerol supported $P$. pastoris cells growth without inducing the AOX promoter [43], however, Bara et al. observed leaky expression from AOX promoter, and functional recombinant protein was detected in bioreactor prior to methanol induction in glycerol-grown $P$. pastoris cultivation [20]. In any case, pre-induction phase cultivation should be optimized to maximize recombinant protein production.

The methanol not only induces the AOX1 promoter in $P$. pastoris for recombinant protein production, but it is also the carbon/energy source. The methanol concentration seriously affects cell uptake rate and specific production rate. Notably, excess of methanol led to accumulation of formaldehyde to toxic level and reduced biomass yield [44]. Methanol is assimilated vigorously with DO consumption. The oxygen demand not only associates with the cellular electron transport, but alcohol oxygenase also requires molecular oxygen as a substrate [45]. In this study, methanol feeding rate was adjusted to response to online measured fermentation parameter - DO, which was kept fluctuating around fixed value. Methanol intake (feeding) rate gradually increased as described in Materials and Methods. And as shown in Fig. 6a, 


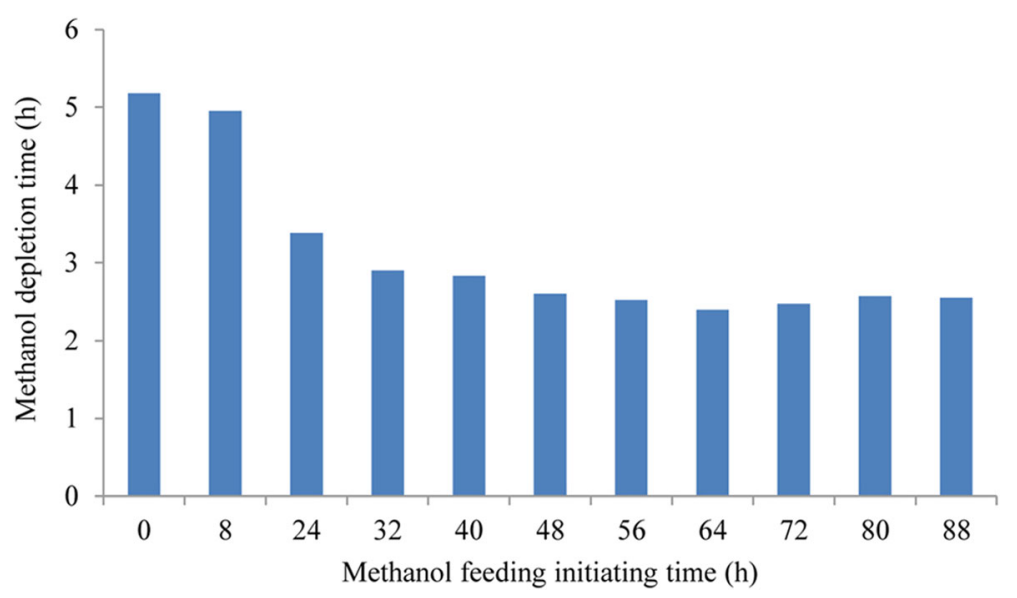

Fig. 4 Methanol depletion time with different methanol feeding initiating time in $1 \mathrm{~L}$ bioreactor

in the initial $72 \mathrm{~h}$ of methanol induction, methanol intake was adapted to the equation:

$$
\begin{aligned}
\mathrm{MI} & =0.1984 \mathrm{~m}_{\text {time }}{ }^{2} \\
& +23 \mathrm{~m}_{\text {time }}-30.286\left(\mathrm{R}^{2}=0.9989\right)
\end{aligned}
$$

where MI was methanol intake, $\mathrm{m}_{\text {time }}$ was methanol induction time. The xylanase activity increased with $\mathrm{m}_{\text {time }}$ and finally reached a plateau (Fig. 5). It was fitted for equation:

$$
\begin{aligned}
\mathrm{Xa}= & -0.0015 \mathrm{~m}_{\text {time }}{ }^{3} \\
& +0.2184 \mathrm{~m}_{\text {time }}{ }^{2}-1.285 \mathrm{~m}_{\text {time }} \\
& +28.034\left(\mathrm{R}^{2}=0.9842\right)
\end{aligned}
$$

where Xa was xylanase activity. The predicted maximum xylanase activity was $591.2 \mathrm{U} / \mathrm{mL}$ when methanol was fed for $94.0 \mathrm{~h}$ according to Eq. 2 and extreme value theorem, and the actual maximum xylanase activity was $560.7 \mathrm{U} /$
$\mathrm{mL}$, which was 7.05 times of that in shake flask. The linear dependence of xylanase activity on methanol intake in initial $72 \mathrm{~h}$ of methanol induction was observed (Fig. 6b), and the resulting equation:

$$
\mathrm{Xa}=0.1906 \mathrm{MI}+1.5033\left(\mathrm{R}^{2}=0.9726\right)
$$

At the end of total cultivation, the DCW reached $53.48 \mathrm{~g} / \mathrm{L}$ in $50 \mathrm{~L}$ bioreactor, far more than that in shake flask (Fig. 5). Both xylanase activity and DCW were significantly improved through novel glycerol and methanol fed-batch strategies in high cell-density fermentation.

\section{Characterization of xylanase activity under high $\mathrm{pH}$ and temperature}

The optimal temperature of xylanase has been proved to be $80{ }^{\circ} \mathrm{C}$ at the optimal $\mathrm{pH} 8.0$ [25]. We evaluated the residual xylanase activity at $50{ }^{\circ} \mathrm{C}$ with different incubation time in a range of $\mathrm{pH} 8.0-11.0$. It showed

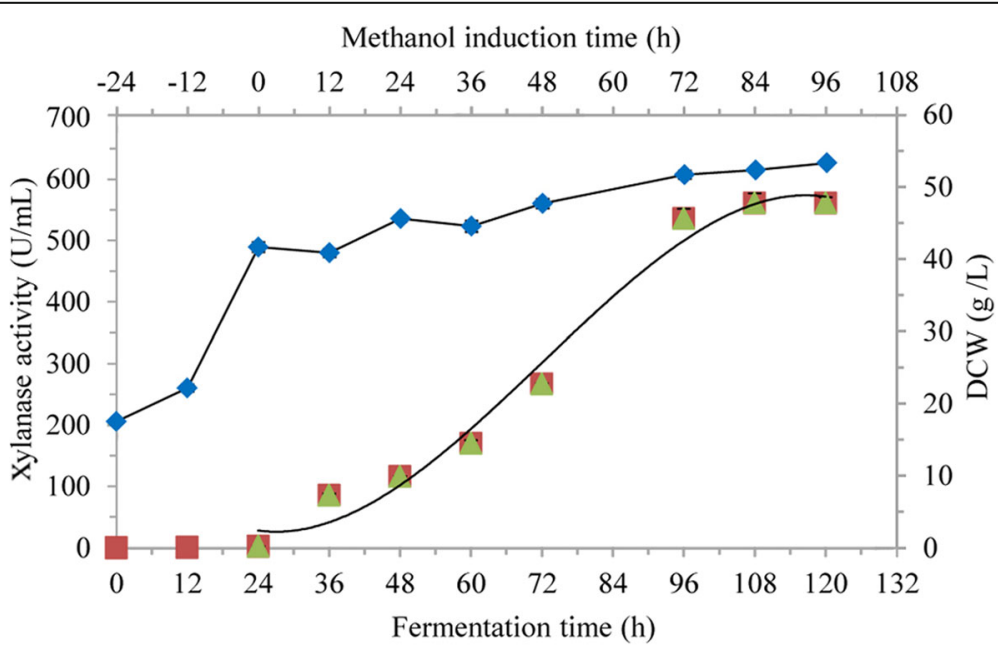

Fig. 5 Recombinant xylanase production in P. pastoris in $50 \mathrm{~L}$ bioreactor 

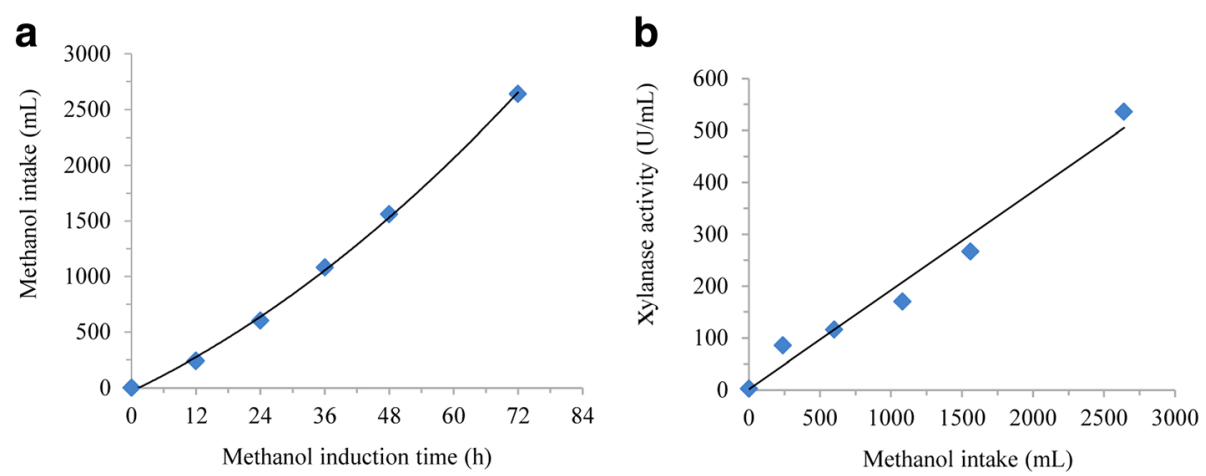

Fig. 6 Time-course of methanol intake and dependence of xylanase activity on methanol intake in 50-L bioreactor. a time-course of the methanol intake, $\mathbf{b}$ linear dependence of xylanase activity on methanol intake

excellent $\mathrm{pH}$ stability. After pre-incubating for $11 \mathrm{~h}$, residual xylanase activity was over $95.0 \%$ at $\mathrm{pH} 8.0$, and more than $85.0 \%$ of xylanase activity was retained even at pH 11.0 (Fig. 7a). According to Ergun and Calik, the most promising recombinant thermoalkaliphilic xylanase of B. halodurans TSEV1 expressed in P. pastoris retained $50.0 \%$ of its initial activity at $80{ }^{\circ} \mathrm{C}$ for $45 \mathrm{~min}$ (pH 9.0), whose xylanase activity was $502.0 \mathrm{U} / \mathrm{mL}[5,46]$. In this study, residual xylanase activity was still over $80.0 \%$ after pre-incubation at $80{ }^{\circ} \mathrm{C}$ for $50 \mathrm{~min}(\mathrm{pH} \mathrm{8.0)}$ ); about $90.0 \%$ of its initial activity was retained at $70{ }^{\circ} \mathrm{C}$ for $60 \mathrm{~min}$ (pH 8.0) (Fig. 7b). This xylanase with high $\mathrm{pH}-$ and temperature tolerance showed potential in industry, especially in the pulp and paper industry [6]. The bioprocess will be more economical and feasible when the labor intensive $\mathrm{pH}$ and temperature readjustment step is trimmed down [47].

\section{Long-term storage stability}

Enzyme stability is a critical factor for industrial application [48]. The fermentation broth was stored at $-20{ }^{\circ} \mathrm{C}$ for 1 year to analyze xylanase activity. The residual xylanase activity was $99.6 \%$ after 1 year, providing important support for xylanase to apply widely.

\section{Conclusions}

Recombinant thermoalkaliphilic xylanase production in $P$. pastoris was enhanced by fermentation parameters optimization. Glycerol and methanol feeding strategies were the critical factors leading to the difference of DCW and xylanase activity between in bioreactor and in shake flask. Novel efficient glycerol and methanol fed-batch strategies were developed to improve xylanase activity to be $560.7 \mathrm{U} / \mathrm{mL}$ in high cell-density fermentation in $50 \mathrm{~L}$ bioreactor, and should be applied in other P. pastoris fermentation for recombinant proteins production. Recombinant xylanase with high stability in the broad temperature $\left(60-80{ }^{\circ} \mathrm{C}\right)$ and $\mathrm{pH}$ (pH 8.0-11.0) ranges was suitable for various industrial applications such as detergent, textile, and paper and pulp industry.
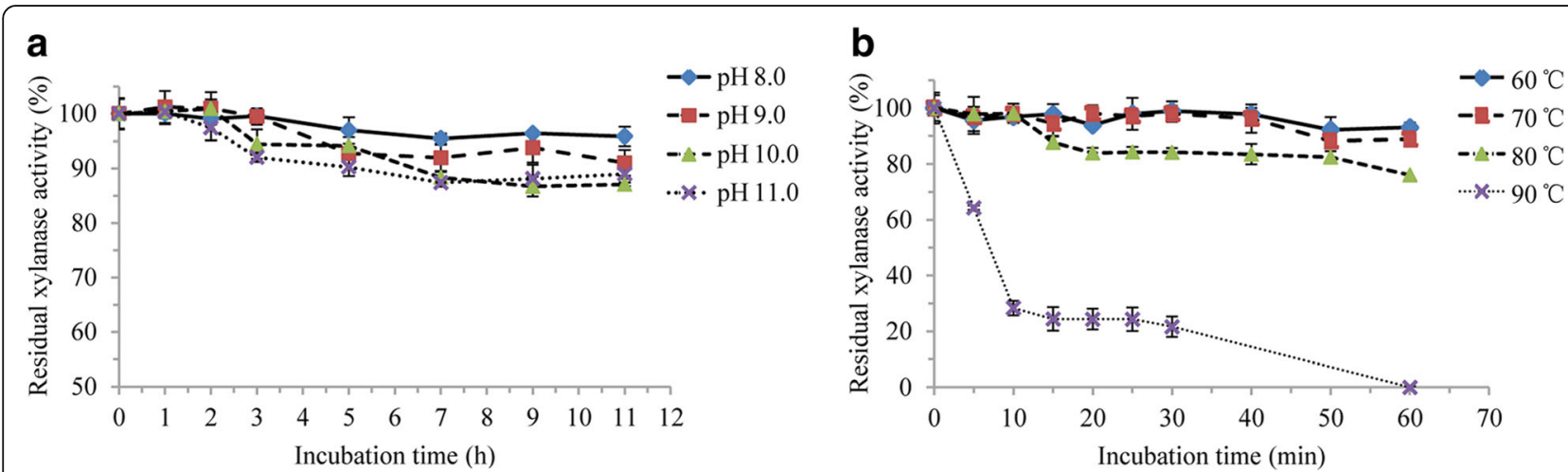

Fig. 7 The properties of recombinant xylanase. $\mathbf{a}$ effect of $\mathrm{pH}$ on the stability of recombinant xylanase, $\mathbf{b}$ effect of temperature on the stability of recombinant xylanase 


\section{Abbreviations}

AOX1: Alcohol oxidase 1; BMGY: Buffered glycerol-complex medium; DCW: Dry cell weight; DNS: Dinitrosalicylic acid; DO: Dissolved oxygen; E. coli: Escherichia coli; EDTA: Ethylenediaminetetraacetic acid; NSPs: Nonstarch polycaccharides; P. pastoris: Pichia pastoris; PMSF: Phenylmethylsulfonyl fluoride; YNB: Yeast nitrogen base; YPD: Yeast extract peptone dextrose medium

\section{Acknowledgements}

Not applicable.

\section{Funding}

This research was supported by the 'Five-twelfth' National Science and Technology Support Program of China (2011BAD26B0403).

\section{Availability of data and materials}

All data generated or analyzed during this study are included in this published article.

\section{Authors' contributions}

TS and DS designed and conducted the experiment, analyzed the data and drafted this manuscript. DZ and XL supported data analysis and read the proof manuscript. LZ participated in shake flask fermentation. CH and YF participated in $1 \mathrm{~L}$ bioreactor fermentation. RZ is the leader of the group and led the work All authors read and approved the final manuscript.

\section{Competing interests}

The authors declare that they have no competing interests.

\section{Consent for publication}

Not applicable.

Ethics approval and consent to participate Not applicable.

\section{Publisher's Note}

Springer Nature remains neutral with regard to jurisdictional claims in published maps and institutional affiliations.

\section{Author details}

'Laboratory of Feed Biotechnology, State Key Laboratory of Animal Nutrition, College of Animal Science \& Technology, China Agricultural University, No.2 Yuanmingyuan West RoadHaidian District, Beijing 100193, China. ${ }^{2}$ College of Animal Science and Technology, Henan University of Science and Technology, Luoyang 471003, China.

\section{Received: 16 January 2017 Accepted: 20 April 2017}

\section{Published online: 21 June 2017}

\section{References}

1. Cayetano-Cruz M, de los Santos AIP, Garcia-Huante Y, Santiago-Hernandez A, Pavon-Orozco P, Lopez VELY, Hidalgo-Lara ME. High level expression of a recombinant xylanase by Pichia pastoris cultured in a bioreactor with methanol as the sole carbon source: Purification and biochemical characterization of the enzyme. Biochem Eng J. 2016;112:161-9.

2. Van Dyk JS, Pletschke BI. A review of lignocellulose bioconversion using enzymatic hydrolysis and synergistic cooperation between enzymes-Factors affecting enzymes, conversion and synergy. Biotechnol Adv. 2012:30:1458-80.

3. Sa-Pereira P, Paveia H, Costa-Ferreira M, Aires-Barros MR. A new look at xylanases - An overview of purification strategies. Mol Biotechnol. 2003;24: $257-81$

4. Martin-Sampedro R, Rodriguez A, Ferrer A, Garcia-Fuentevilla LL, Eugenio ME. Biobleaching of pulp from oil palm empty fruit bunches with laccase and xylanase. Bioresour Technol. 2012;110:371-8.

5. Ergun BG, Calik P. Lignocellulose degrading extremozymes produced by Pichia pastoris: current status and future prospects. Bioprocess Biosyst Eng. 2016:39:1-36.

6. Lin XQ, Han SY, Zhang N, Hu H, Zheng SP, Ye YR, Lin Y. Bleach boosting effect of xylanase A from Bacillus halodurans C-125 in ECF bleaching of wheat straw pulp. Enzyme Microb Tech. 2013;52:91-8.
7. Ahmad M, Hirz M, Pichler H, Schwab H. Protein expression in Pichia pastoris: recent achievements and perspectives for heterologous protein production. Appl Microbiol Biotechnol. 2014;98:5301-17.

8. Gmeiner C, Saadati A, Maresch D, Krasteva S, Frank M, Altmann F, Herwig C, Spadiut O. Development of a fed-batch process for a recombinant Pichia pastoris Delta och1 strain expressing a plant peroxidase. Microbial Cell Factories. 2015;14:1.

9. Hahn-Hagerdal B, Karhumaa K, Larsson CU, Gorwa-Grauslund M, Gorgens J, van Zyl WH. Role of cultivation media in the development of yeast strains for large scale industrial use. Microbial cell factories. 2005;4:31.

10. Macauley-Patrick S, Fazenda ML, McNeil B, Harvey LM. Heterologous protein production using the Pichia pastoris expression system. Yeast. 2005;22:249-70.

11. Jahic M, Veide A, Charoenrat T, Teeri T, Enfors SO. Process technology for production and recovery of heterologous proteins with Pichia pastoris. Biotechnol Prog. 2006;22:1465-73.

12. Jahic M, Rotticci-Mulder JC, Martinelle M, Hult K, Enfors SO. Modeling of growth and energy metabolism of Pichia pastoris producing a fusion protein. Bioprocess Biosyst Eng. 2002;24:385-93.

13. Salehmin MNI, Annuar MSM, Chisti Y. High cell density fed-batch fermentations for lipase production: feeding strategies and oxygen transfer. Bioprocess Biosyst Eng. 2013;36:1527-43.

14. Wang JR, Li YY, Liu DN. Improved Production of Aspergillus usamii endobeta-1,4-xylanase in Pichia pastoris via Combined Strategies. Biomed Res Int. 2016;2016:3265895.

15. Cereghino GPL, Cereghino JL, Ilgen C, Cregg JM. Production of recombinant proteins in fermenter cultures of the yeast Pichia pastoris. Curr Opin Biotech. 2002;13:329-32

16. $\operatorname{Cos} \mathrm{O}$, Ramon R, Montesinos JL, Valero F. Operational strategies, monitoring and control of heterologous protein production in the methylotrophic yeast Pichia pastoris under different promoters: A review. Microbial cell factories. 2006;5:17.

17. Zhou XY, Yu Y, Tao JJ, Yu L. Production of LYZL6, a novel human c-type lysozyme, in recombinant Pichia pastoris employing high cell density fedbatch fermentation. J Biosci Bioeng. 2014;118:420-5.

18. Zhang WH, Potter KJH, Plantz BA, Schlegel VL, Smith LA, Meagher MM. Pichic pastoris fermentation with mixed-feeds of glycerol and methanol: growth kinetics and production improvement. J Ind Microbiol Biot. 2003;30:210-5.

19. Fang ZG, Xu L, Pan DJ, Jiao LC, Liu ZM, Yan YJ. Enhanced production of Thermomyces lanuginosus lipase in Pichia pastoris via genetic and fermentation strategies. J Ind Microbiol Biot. 2014;41:1541-51.

20. Bawa Z, Routledge SJ, Jamshad M, Clare M, Sarkar D, Dickerson I, Ganzlin M, Poyner DR, Bill RM. Functional recombinant protein is present in the preinduction phases of Pichia pastoris cultures when grown in bioreactors, but not shake-flasks. Microbial cell factories. 2014;13:127.

21. Zheng J, Zhao W, Guo N, Lin FL, Tian J, Wu LS, Zhou HB. Development of an industrial medium and a novel fed-batch strategy for high-level expression of recombinant beta-mananase by Pichia pastoris. Bioresource Technol. 2012;118:257-64.

22. Zhao W, Wang JW, Deng RQ, Wang XZ. Scale-up fermentation of recombinant Candida rugosa lipase expressed in Pichia pastoris using the GAP promoter. J Ind Microbiol Biot. 2008;35:189-95.

23. Markošová $K$, Weignerová $L$, Rosenberg $M$, Křen V, Rebroš M. Upscale of recombinant alpha-L-rhamnosidase production by Pichia pastoris Mut(S) strain. Front Microbiol. 2015:6:1140

24. Ding J, Gao MJ, Hou GL, Liang KX, Yu RS, Li Z, Shi ZP. Stabilizing porcine interferon-alpha production by Pichia pastoris with an ethanol on-line measurement based DO-Stat glycerol feeding strategy. J Chem Technol Biot. 2014;89:1948-53.

25. Zhao LM, Geng J, Guo YQ, Liao XD, Liu XH, Wu RJ, Zheng ZJ, Zhang RJ. Expression of the Thermobifida fusca xylanase Xyn11A in Pichia pastoris and its characterization. Bmc Biotechnol. 2015;15:18.

26. Li YY, Zhong KX, Hu AH, Liu DN, Chen LZ, Xu SD. High-level expression and characterization of a thermostable xylanase mutant from Trichoderma reesei in Pichia pastoris. Protein Expres Purif. 2015;108:90-6.

27. Bailey MJ, Biely P, Poutanen K. Interlaboratory testing of methods for assay of xylanase activity. J Biotechnol. 1992;23:257-70.

28. Miller GL. Use of dinitrosalicylic acid reagent for determination of reducing sugar. Anal Chem. 1959;31:426-8

29. Hellwig S, Emde F, Raven NPG, Henke M, van der Logt P, Fischer R. Analysis of single-chain antibody production in Pichia pastoris using on-line methanol control in fed-batch and mixed-feed fermentations. Biotechnol Bioeng. 2001;74:344-52. 
30. Inan $\mathrm{M}$, Meagher MM. The effect of ethanol and acetate on protein expression in Pichia pastoris. J Biosci Bioeng. 2001;92:337-41.

31. Delabona PD, Farinas CS, Lima DJD, Pradella JGD. Experimental mixture design as a tool to enhance glycosyl hydrolases production by a new Trichoderma harzianum P49P11 strain cultivated under controlled bioreactor submerged fermentation. Bioresource Technol. 2013;132:401-5.

32. Maes C, Delcour JA. Structural characterisation of water-extractable and waterunextractable arabinoxylans in wheat bran. J Cereal Sci. 2002;35:315-26.

33. Majzoobi M, Pashangeh S, Farahnaky A, Eskandari MH, Jamalian J. Effect of particle size reduction, hydrothermal and fermentation treatments on phytic acid content and some physicochemical properties of wheat bran. J Food Sci Tech Mys. 2014;51:2755-61.

34. Wood IP, Cook NM, Wilson DR, Ryden P, Robertson JA, Waldron KW. Ethanol from a biorefinery waste stream: Saccharification of amylase, protease and xylanase treated wheat bran. Food Chem. 2016;198:125-31.

35. Perez-Rodriguez N, Oliveira F, Perez-Bibbins B, Belo I, Agrasar AT, Dominguez JM. Optimization of xylanase production by filamentous fungi in solid-state fermentation and scale-up to horizontal tube bioreactor. Appl Biochem Biotechnol. 2014;173:803-25.

36. Simkhada JR, Yoo HY, Choi YH, Kim SW, Yoo JC. An extremely alkaline novel xylanase from a newly isolated streptomyces strain cultivated in corncob medium. Appl Biochem Biotechnol. 2012;168:2017-27.

37. Zhang ZC, Li JS, Feng F, Liu D, Pang QX, Li M, Chen KP. Optimization of nutrition constituents for xylanase activity by Rhizopus stolonifer under solidstate fermentation on corncob. Bioresources. 2013;8:2018-32.

38. Gorgens JF, van Zyl WH, Knoetze JH, Hahn-Hagerdal B. Amino acid supplementation improves heterologous protein production by Saccharomyces cerevisiae in defined medium. Appl Microbiol Biotechnol. 2005;67:684-91.

39. Werten MWT, Van den Bosch TJ, Wind RD, Mooibroek H, De Wolf FA. Highyield secretion of recombinant gelatins by Pichia pastoris. Yeast. 1999;15: 1087-96.

40. Albers E, Larsson C, Liden G, Niklasson C, Gustafsson L. Influence of the nitrogen source on Saccharomyces cerevisiae anaerobic growth and product formation. Appl Environ Microb. 1996;62:3187-95.

41. Singh S, Gras A, Fiez-Vandal C, Ruprecht J, Rana R, Martinez M, Strange PG, Wagner R, Byrne B. Large-scale functional expression of WT and truncated human adenosine $\mathrm{A}(2 \mathrm{~A})$ receptor in Pichia pastoris bioreactor cultures Microbial cell factories. 2008;7:28

42. Sibirny AA, Titorenko VI, Gonchar MV, Ubiyvovk VM, Ksheminskaya GP, Vitvitskaya OP. Genetic-control of methanol utilization in yeasts. J Basic Microb. 1988;28:293-319.

43. Weinhandl K, Winkler M, Glieder A, Camattari A. Carbon source dependent promoters in yeasts. Microbial cell factories. 2014;13:5.

44. Khatri NK, Hoffmann F. Impact of methanol concentration on secreted protein production in oxygen-limited cultures of recombinant Pichia pastoris. Biotechnol Bioeng. 2006;93:871-9.

45. Lee CY, Lee SJ, Jung KH, Katoh S, Lee EK. High dissolved oxygen tension enhances heterologous protein expression by recombinant Pichia pastoris. Process Biochem. 2003:38:1147-54.

46. Kumar V, Satyanarayana T. Generation of xylooligosaccharides from microwave irradiated agroresidues using recombinant thermo-alkali-stable endoxylanase of the polyextremophilic bacterium Bacillus halodurans expressed in Pichia pastoris. Bioresource Technol. 2015;179:382-9.

47. Kumar V, Satyanarayana T. Biochemical and thermodynamic characteristics of thermo-alkali-stable xylanase from a novel polyextremophilic Bacillus halodurans TSEV1. Extremophiles. 2013;17:797-808.

48. Soozanipour A, Taheri-Kafrani A, Isfahani AL. Covalent attachment of xylanase on functionalized magnetic nanoparticles and determination of its activity and stability. Chem Eng J. 2015;270:235-43.

\section{Submit your next manuscript to BioMed Central and we will help you at every step:}

- We accept pre-submission inquiries

- Our selector tool helps you to find the most relevant journal

- We provide round the clock customer support

- Convenient online submission

- Thorough peer review

- Inclusion in PubMed and all major indexing services

- Maximum visibility for your research

Submit your manuscript at www.biomedcentral.com/submit

) Biomed Central 